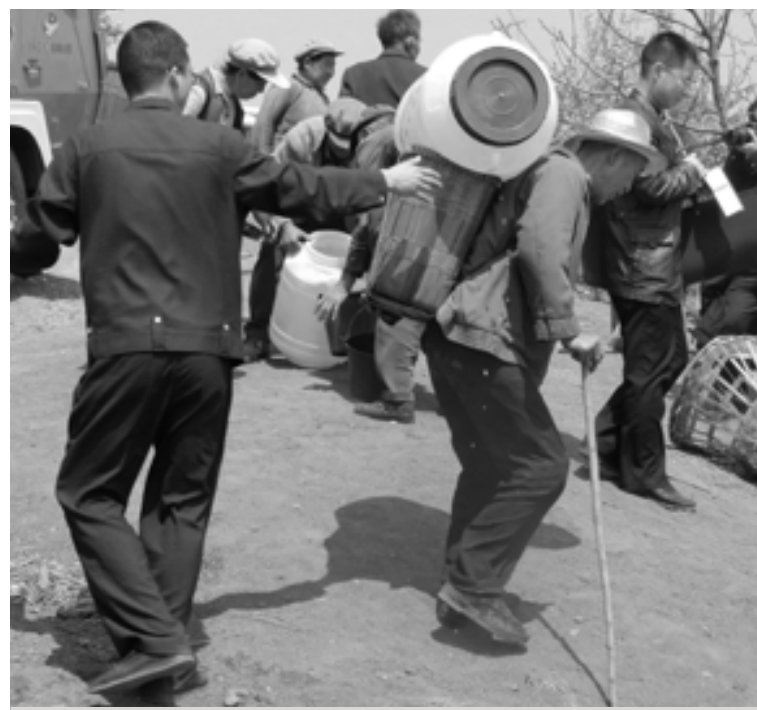

A water delivery initiative in northwest Yunnan. Famers receive barrels of drinking water from the government while fresh water from local springs is impounded and diverted elsewhere. Photo: Andrea E. Pia

\section{A Water Commons in China?}

\section{Andrea E. Pia}

The debate over China's environmental issues has given scant consideration to already existing popular alternatives to the topdown, growth-compatible governance of the country's natural resources. Forty years of Party-sanctified insistence on pursuing relentless economic development has seemingly suppressed alternative discourses in natural resource management. However, if we take closer look, we will find that at the grassroots there is no lack of alternatives. For instance, in contemporary rural China there are places where water is being managed as a commons.
As a one-time campaigner for the 2011 Italian Referendum against the privatisation of the country's domestic water services, I was excited to discover during fieldwork in Yunnan province that when briefed and asked about their views on the referendum proposals, most of my informants in the water sector were in fact sympathetic to them. They similarly hoped to protect water from marketisation and demanded the democratisation of its management.

As I write this essay, an ethnographic scene comes to mind. One day in 2012, I took part in negotiations between a Village Committee and a public-private enterprise regarding a water conservancy project that would have required the relocation of several of the village's households. The Committee pointed out that the proposed project mainly benefited the enterprise, which would gain access to state subsidies regardless of the efficacy of their infrastructure. The enterprise was legally required to win the Committee's assent to the project. To do so, they eventually had to accede to the local Party Secretary's request that the enterprise build a number of free-of-charge water dispensers for the newly relocated households at its own expense. Cases of political strong-arming for the sake of public access to water such as this had also been typical of Italian campaigners in the runup to the referendum. But such similarities begs the question: if Chinese people involved in everyday water politics were thinking along similar lines to Italian water activists, what was pre-empting the emergence of a similar movement in China? Obviously, the two countries are characterised by divergent political traditions and conceptions of social and environmental justice-for instance, a referendum is a not an option in China. However, in this essay I will explore whether the answer may have something to do with the thus far poorly theorised question of the Commons in China.

In what follows I will argue that in contemporary rural China there are places 
where water is already being managed as a commons. Making fresh water a commonly held resource entails breaking with global practices of water management in three ways. First, water has to lose its status as a commodity and be re-defined as a flowing component of the environment. When water is reconceptualised as a commons, the continuous local availability of its nurturing flow gains prominence over the marketmediated relationship between its supply and demand. Here, the notion of a nurturing flow illuminates the broadly defined lifesupporting functions exerted by water within both human and non-human ecosystems. Second, from the point of view of its management, water services cease to be run for profit, return on capital invested in water infrastructure lowers to zero, and ownership is reframed as a shared obligation to universal and sustainable provision. Finally, water services are opened up to public and associative participation into the crafting, enforcement, and monitoring of relevant rules with a view to preserving the life-nurturing qualities of the water flow over generations, as well as for non-human ecosystems.

\section{The Appeal of Techno- Political Frameworks}

So far the debate about China's current environmental issues has given little consideration to already existing popular alternatives to the top-down, growthcompatible governance of the country's endangered natural resources. Forty years of Party-sanctified insistence on pursuing relentless economic development has seemingly muffled the few dissenting voices and suppressed alternative discourses in natural resource management-such as those concerned with stewardship, care, maintenance, or even rejuvenation of the Chinese environment.

Instead, the language of techno-politics is holding sway. This is a mix of legal tweaks and engineering innovations-for instance, those behind the introduction of tradable water permits and huge water diversion schemeswhich, by preaching the appealing fantasy of the harmonious coexistence of China's present capitalist mode of development with nature, have slowly won over many of China's most belligerent environmentalists. Surprisingly, the case for the coexistence of continuous growth and sustainability has arguably found a favourable, if unlikely, currency for its propagation in the political doctrine of 'Ecological Civilisation' (shengtai wenming). While proposing a re-orientation of China's current model of growth (hailed by a felicitous start and some early success stories), in the sanitised version currently peddled by the Chinese government, Ecological Civilisation actually seems to be working to reinforce a chauvinistic and system-preserving distrust in local people's ability to redress the imbalance between efficiency in resource use and equity in allocation. What gets de-emphasised in the institutionalisation of Ecological Civilisation is the potential offered by empowering communities to democratically take environmentally sensitive decisions for themselves. Redressing this imbalance appears to me as a valuable short-term goal if at least to avoid some of the most obnoxious unintended consequences of techno-politics.

\section{A Problem of 'Distribution of the Sensible'}

The dominance of the top-heavy technopolitics of sustainability in China renders local people incapable of articulating and implementing alternatives. That does not mean to say that local people have no interest in developing alternative ways of dealing with environmental crises. Indeed, a good deal of empirical work has recently suggested that concrete local alternatives to businessas-usual are, if anything, in very high- 
demand, especially for those at the periphery of contemporary Chinese society. Citizens at the losing end of economic developmentincluding rural resettlers, ethnic minorities, and others-are all aware that environmental degradation is impacting them first. For instance, those who have to figure out how to fetch their clean water everyday usually seek out workable alternatives more pressingly than environmentally-blind urbanites. The analytical problem is, therefore, one of recognising the political agency of those who are elaborating viable counter-practices.

While the people directly engaged with the governance of natural resources may themselves ignore the extent to which the alternatives they put to work can be identified as sustainable or even counterparadigmatic within China's institutional architecture, the problem at stake here is one of visibility-or as Rancière would put it, one of the 'distribution of the sensible'. Rancière suggests that political fault lines are perceivable only to the groups who are sitting by them-in our case disenfranchised farmers living in water dispossessed communitieswhile their capacity to effectively overcome common predicaments in any political consequential way is publicly denied to them by their very proximity to such fault lines. Thus, counter-practices and counterenunciation are rendered unintelligible to anyone, their supporters included.

Public recognition does not just make alternative political practices widely known, but also efficacious. Up until now, the multifarious sustainability proposals championed by the Chinese government have taken the lion's share of the public debate on sustainability in the country, so much so that the very people who are concretely engaging with political practices of responsible, equitable, and un-marketed stewardship of common resources in contemporary China are not able to call them for what they are. Even worse, they struggle to see them as being in discontinuity from the demonstrably short-term solutions ushered in by those who consider the environmental question a technical problem requiring nothing more than the tools available within the imaginative horizon of capitalism.

\section{Canal Managers of Erstwhile}

Between 2011 and 2013, I spent eighteen months working with water bureaucrats and farmers as they went about implementing changes in the provision of irrigation and drinking water in their county. During this time, the price of drinking water doubled and the two local water agencies in charge of tax collection, infrastructure upkeep, and water development were transferred to hard budget accounts. Meanwhile, state and private funds were being diverted towards nearby cities. Farmers were also asked to reinvent themselves as members of Water Users' Associations (WUAs), alien organisations handed down to villagers by Mandarin-speaking universitytrained officials aimed at making the service more responsive to local needs and, most importantly, cheaper. Farmers were suddenly told to become familiar with the new norms that regulated the use, control, and exchange rights over water. They were warned that the government would hold them responsible for mismanaging the service they were now instructed to provide. During inaugural WUA meetings, the language of techno-politics was extensively used. While most of what was said would make direct reference to the science of the Commons, the farmers understood that they would now have to work for free as canal managers (guanzhang).

Prior to the advent of WUAs, being a canal manager had, in fact, been something everyone in this part of Yunnan was quite familiar with. It was a democratic and collectively financed position to which farmers were appointed on a rotating basis, according to a broader system of rules on local water management. Farmers appointed canal managers on every single 
portion of a canal adjoining a field or a house. They entrusted neighbouring members of this infrastructural community with reporting any misdelivery of water nearby. If managers were found guilty of mismanagement, a democratically appointed middlemanbacked by the local Village Committeewould identify a different manager for that portion of the canal until the next incident. A similar system of distributed responsibility and participation in monitoring existed for a network of privately-built, but collectivelyused, water wells widely accessible throughout the community. In essence, people from this area of Yunnan were managing the local water supply as a common resource and were doing it effectively. This system was run as a service to the community and not for profit. Rules to punish overdrawing had also been in force at some point, but were later abandoned as state officials took charge over environmental issues.

\section{The Activation of Ineluctability}

What is most surprising is not that local people were aware and had extensive experience of cooperating on water management well before anyone from the outside had instructed them on the matter. Rather, the surprising bit of this story is that local farmers were willing to accept the cooptation of their distributed and equitable mechanism of organised water delivery. This, at the hands of a system that promised nothing except increased levels of corruption, higher overall running costs, and dwindling state support.

Indeed, the language of techno-politics is successful because it activates a particular explanatory framework that resonates among the people-that of the moral superiority of scientific management. Farmers would assert that countryside life was bound to disappear in China and that rural dwellers had to adjust to a different lifestyle or migrate elsewhere.
In their opinion, the previous system was backward and not keeping pace with more scientific forms of management represented by the WUAs. While a few younger informants held the view that locals should collectively resist the government or businesses whenever water was taken away or polluted, in general the water sector reformers had been quite successful in framing the problem of sustainability exclusively as one of science and supervision. The idea of governing water 'the old way' (laoguiju) was thereby made redundant-a survival component of an important, but now technically disposable, condition of pre-scientific Chinese water management. As mentioned above, one key idea of the notion of the Commons is that of inclusive participation in the decisionmaking process concerning the management of natural resources. As this power seemingly fades away from north-east Yunnanese communities, so is the sense of meaningfully being part of one's community and the capacity to care for it. The Rancierian gesture I resorted to here was to acknowledge the unrecognised capacity of local Chinese people to challenge the tacit ordering and distribution of the things we have in common in counter-paradigmatic ways. As one Italian water referendum campaigner used to say during activists' assemblies: 'They want to convince us we don't care about how water gets delivered.' My ethnography shows that it is about time we start to re-convince ourselves of the contrary.

\section{Andrea E. Pia}

Andrea E. Pia is a Fellow in the Anthropology of China at the London School of Economics and Political Science. His research examines Yunannese street-level officials and rural residents as they push the boundaries of cooperation and antagonism over the task of maintaining access to water in the Chinese periphery. 